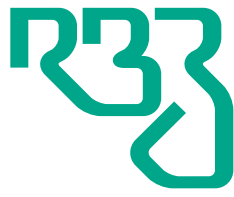

Brasileira de Zootecnia

Brazilian Journal of Animal Science

ISSN 1806-9290

www.rbz.org.br

\title{
Partial replacement of soybean meal with pea grains and sunflower cake in ewe diets: milk quality and blood biochemical parameters
}

\author{
Zvonko Antunović $^{1}$ (iD, Marcela Šperanda ${ }^{1}$ (iD), Boro Mioč ${ }^{2}$ (iD), Željka \\ Klir $^{1 *}$ iD, Suzana Ćavar ${ }^{3}$ iD, Josip Novoselec ${ }^{1}$ iD \\ ${ }^{1}$ Josip Juraj Strossmayer University of Osijek, Faculty of Agrobiotechnical Sciences Osijek, \\ Department for Animal Production and Biotechnology, Osijek, Croatia. \\ ${ }^{2}$ University of Zagreb, Faculty of Agriculture, Department of Animal Science and Technology, \\ Zagreb, Croatia \\ ${ }^{3}$ Institute of Public Health of the Osijek-Baranja County, Osijek, Croatia.
}

\author{
*Corresponding author: \\ zklir@fazos.hr \\ Received: July 6, 2018 \\ Accepted: April 16, 2019 \\ How to cite: Antunović, Z.; Šperanda, M.; Mioč, \\ B.; Klir, Ž.; Ćavar, S. and Novoselec, J. 2019. \\ Partial replacement of soybean meal with pea \\ grains and sunflower cake in ewe diets: milk \\ quality and blood biochemical parameters. \\ Revista Brasileira de Zootecnia 48:e20180140 \\ https://doi.org/10.1590/rbz4820180140
}

Copyright: This is an open access article distributed under the terms of the

Creative Commons Attribution License (http://creativecommons.org/licenses/by/4.0/), which permits unrestricted use, distribution, and reproduction in any medium, provided the original work is properly cited.

\begin{abstract}
The objective of this research was to evaluate the effect of pea and sunflower cake as partial replacement for soybean meal in diet, as well as to assess their effect on milk quality during lactation and on blood parameters of ewes kept in organic farming. The research was carried out with 30 ewes of Merinolandschaf breed during 75 days. Ewes were given mixtures based on soybean meal as a protein source in control group (SBM), while in experimental groups, soybean meal was partially replaced with pea grain (P) and sunflower cake (SFC). Biochemical parameters (urea, glucose, total protein, albumin, globulins, cholesterol, HDL, LDL, triglyceride, $\beta$-hydroxybutyrate, and non-esterified fatty acids), as well as enzyme activity (ALT, AST, ALP, GGT, and CK) were determined in blood of ewes. Milk composition and concentration of fatty acids in milk fat were also determined. In comparison with control, sunflower cake as a protein source affected the increase of fat content in milk. When compared with pea grain and SBM, it decreased the urea concentration in milk. Oleic acid, total monounsaturated fatty acids, and n- 6 increased, while saturated fatty acids, atherogenic, and thrombogenic indices decreased in SFC. Feeding ewes with peas increased the content of n-3 fatty acids in their milk. If compared to SFC, it also improved the n-6:n-3 ratio. Partial replacement of soybean meal with SFC reduced the blood concentration of total protein, globulin, and AST, and GGT enzyme activities and increased the $\beta$-hydroxybutyrate. Inclusion of pea grain and SFC can be adequately used as partial replacement of soybean meal in feeding of ewes kept in organic farming.
\end{abstract}

Keywords: blood parameters, ewes, milk composition, protein source

\section{Introduction}

In ruminant nutrition, soybean and its byproducts are often used as source of protein in diets. However, if considering significant imports of soybean in the European Union countries and the fear of the GMO pollution, soybean is not acceptable for feeding of animals in organic production (European Union, 2007). With an increasing interest in organic sheep production, the number of sheep is increasing in Europe (Antunović et al., 2017). A great resource of feed in organic agriculture are grain legume crops, as they can both satisfy the nutritional content of organic livestock feeding and maintain soil fertility (Sarhan, 2011). Pea (Pisum sativum) is a legume crop rich in proteins (23-34\%), especially in globulin and albumin (70-95\%), with a good balance of essential amino acids. In addition to proteins, pea is a good source of starch (over $40 \%$ of dry matter), which assures good quality and high-energy resource in animal feeding (Jezierny et al., 2010). Both sunflower seeds and cake have become alternative feeds 
for ruminants (Alves et al., 2016). In Southeastern Europe, sunflower cake (SFC) is already traditionally used in organic animal feeding as protein and fat source. Sunflower cake is an excellent source of nutrients for ruminants because it is composed of oil rich in polyunsaturated fatty acids (PUFA; $65.3 \%)$ and characterized by crude protein content (22-34\% DM) and high dry matter digestibility (approximately 65\%; Santos et al., 2015; Nagalakshmi et al., 2011). Besides, Wanderley Junior et al. (2018) reported that sunflower meal is suitable for replacing conventional concentrates, providing lamb meat with lower concentrations of $n-6$ without reducing $n-3$ polyunsaturated fatty acids (PUFA). It is well known that dietary fat may influence the fat content of ewe milk and biochemical parameters of their blood. In recent years, consumers are becoming more conscious of the link between diet, disease, and food components and how they can influence health status (Goes et al., 2017).

Biochemical parameters in animal blood are a reliable assessment criterion of their nutritional status, health, and welfare (Herdth et al., 2000; Whitney et al., 2009; Antunović et al., 2011). Therefore, determination of these parameters in blood can help to avoid various problems and sub-clinical diseases of animals caused by inadequate nutrition. Partial or complete replacement of soybean meal (SBM) with pea (Cozzi et al., 2010; Antunović et al., 2013; Bonanno et al., 2015) or SFC (Santos et al., 2015) in ruminant feeding causes no significant differences in production traits or quality of products.

So far, not many studies have been performed on biochemical parameters in sheep blood, in particular with the addition of SFC in sheep diets. Therefore, the objective of the present study was to investigate the effect of peas and SFC used as partial replacement for SBM in ewe diet during lactation in organic farming, as well as determine their influence on the quality of milk and blood biochemical parameters of ewes.

\section{Material and Methods}

The local Committee for Animal Welfare confirmed that the present research was carried out by following all legal provisions of the Animal Protection Act (Official Gazette No. 133 since 2006, No. 37 since 2013, and No. 125 since 2013). The research was conducted on a family farm with long tradition of organic sheep farming, situated $35 \mathrm{~km}$ northeast from Osijek $\left(42.150^{\circ} \mathrm{N} ; 52.647^{\circ} \mathrm{E}\right)$ in the area of Baranja (Croatia), settled at an altitude of $91 \mathrm{~m}$.

From a herd of 150 sheep, there were 30 sheep of Merinolandschaf breed selected during suckling period. Apart from uniform physical development, good health, and appropriate physical fitness, criteria for selection of sheep were age (four years), parity (third lactation), stage of lactation ( \pm seven days), and the same number of lambs per litter (two lambs). Lactating Merinolandschaf ewes were homogeneously allocated to three groups based on live weight $(65.15 \pm 6.87 \mathrm{~kg})$ and body condition score (BCS; 3.31 \pm 0.17 ; according to Russel (1991)) and set to the research, which lasted for 75 days. Groups of ewes were marked according to the protein sources in their feed. Ewes in the control group were fed mixtures based on SBM as a protein source, while in experimental groups, SBM was partially replaced with pea grain (P) and SFC.

Housing and feeding of sheep were according to the Council Regulation (EC) No. 834/2007 on organic production and labelling of organic products (European Union, 2007). Ewes were given feeding mixture $(0.6 \mathrm{~kg} /$ day) and hay (ad libitum). Water was constantly available.

Feed mixtures and hay were analyzed for chemical composition and fatty acid concentrations (Table 1). Crude protein content of feed samples was determined by the Kjeldahl method (Pearson, 1976), while ether extract was determined according to the method described by Onwuka (2005); the crude fiber content was determined by the Weende method (Offor et al., 2014); neutral detergent fiber (NDF) was determined according to Foss (2001); and non-fiber carbohydrates were obtained according to the following equation: $(\mathrm{NFC})=100-(\% \mathrm{NDF}+\% \mathrm{CP}+\% \mathrm{EE}+\%$ ash $)$.

Milk sampling was carried out by hand milking on the 30th, 60th, and 90th days of lactation. Milk samples were collected in plastic bottles $(200 \mathrm{~mL})$, transferred in mobile coolers, and cooled to $4{ }^{\circ} \mathrm{C}$ within $24 \mathrm{~h}$ prior to laboratory analysis. Sheep milk was analyzed for dry matter without fat, milk

R. Bras. Zootec., 48:e20180140, 2019 
fat, protein, lactose, urea, and somatic cell count (SCC). Analysis of fat, protein, lactose, and urea concentrations in milk was carried out by infrared spectrometry (ISO 9622: 2001) on the MilkoScan FT 6000 analyzer within Comby system. Somatic cell count was determined by fluoro-opto-electronic method (EN ISO 13366-2 / Correction. 1. 2007) with Fossomatic 5000 analyzer.

To remove fat from milk, it was necessary to shake a specific volume of milk with the organic solvents: ammonia, ethanol, ether, and petroleum ether, and allow the solution to rest to separate the layers. An aliquot of supernatant was evaporated and dried in oven until constant weight (Trajković et al., 1983).

Preparation of fatty acid methyl esters was performed by gas chromatography according to the standard HRN EN ISO 12966-2:2011. Glycerides were saponified with $\mathrm{NaOH}$ in methanol, after which the soaps were converted into fatty acid methyl esters by reaction with $\mathrm{BF}_{3} /$ methanol complex. An amount of $1 \mathrm{~mL}$ of separated heptane layer was transferred into vial for GC-FID analysis. Determination method and applied conditions followed the HRN EN ISO 12966-1:2015 standard. The samples were analyzed by gas chromatograph 7890B (Agilent Technologies, USA) using a 100-m working capillary column Rtx ${ }^{\circledR}-2560$ (biscyanopropyl polysiloxane) with a diameter of $0.25 \mathrm{~mm}$ and the thickness of the stationary phase of 0.20 microns (Restek, USA), a split-splitless injector (temperature of $225^{\circ} \mathrm{C}$ and pressure of 35.8psi) with flame-ionization detector, and temperature of $250^{\circ} \mathrm{C}$. Sample in volume of $1 \mu \mathrm{L}$ was injected into the system. The temperature of the oven in the beginning was $100{ }^{\circ} \mathrm{C}$ with holding time for $4 \mathrm{~min}$, increasing at a rate of $3{ }^{\circ} \mathrm{C} / \mathrm{min}$ to $240^{\circ} \mathrm{C} / \mathrm{min}$ and holding for $11 \mathrm{~min}$. Run time was $61.67 \mathrm{~min}$. Carrier gas was nitrogen (99.9999\%) at constant flow rate of $1.2 \mathrm{~mL} / \mathrm{min}$. The hydrogen flow was $30 \mathrm{~mL} / \mathrm{min}$, air flow was $250 \mathrm{~mL} / \mathrm{min}$, and the makeup gas flow (nitrogen) was $45 \mathrm{~mL} / \mathrm{min}$.

Fatty acid methyl esters were identified by comparison with retention time of 37 fatty acid methyl ester standard. Prior to analysis of samples and standards, certified reference material was prepared and analyzed at the same conditions. The result was expressed as a percentage (\%) of individual fatty acids to total fatty acids. The detection limit was $0.01 \%$.

Atherogenic (AI) and thrombogenic (TI) indices of milk were calculated according to equations of Ulbricht and Southgate (1991):

$\mathrm{AI}=\left[(12: 0+4(14: 0)+16: 0] /\left[(\mathrm{n} 6+\mathrm{n} 3) \mathrm{PUFA}+18: 1+\sum \mathrm{MUFA}\right]\right.$

$\mathrm{TI}=(14: 0+16: 0+18: 0) /[(0.5 \times 18: 1)+0.5($ MUFA $)+0.5(\mathrm{n} 6 \mathrm{PUFA})+3(\mathrm{n} 3 \mathrm{PUFA})+(\mathrm{n} 3 \mathrm{PUFA} / \mathrm{n} 6 \mathrm{PUFA})]$

Index of $\Delta^{9}$-desaturase activity was determined from the following ratios: C14:1/C14:0, C16:1/C16:0, and C18:1/C18:0, and health-promoting index (HI): unsaturated fatty acids / [C12:0 $+(4 \times \mathrm{C} 14: 0)+$ C16:0], according to Chen et al. (2004).

The blood was collected from the jugular vein $(10 \mathrm{~mL})$ into sterile vacuum tubes Venoject ${ }^{\circledR}$ (Sterile Terumo Europe, Leuven, Belgium) on the 30th, 60th, and 90th days of lactation. After that, serum was separated by centrifugation $(10 \mathrm{~min})$ at 3000 revolutions/min and placed into an Olympus AU640 device. Concentrations of biochemical parameters [urea, glucose, total proteins, albumin, cholesterol, HDL cholesterol; LDL cholesterol, triglyceride, $\beta$-hydroxibutyrate (BHB), and non-esterified fatty acids (NEFA)] and enzyme activity (alanine aminotransferase (ALT), aspartate aminotransferase (AST); alkaline phosphatase (ALP), creatine kinase (CK), and $-\gamma$-glutamyl transferase (GGT)] were determined from the blood serum with Olympus System Reagents, manufactured and distributed by Olympus Diagnostic GmbH (Irish Branch), Lismeehan, Ireland. Globulin content was calculated as the difference between total protein and albumin.

Mean values from the present research were obtained by the MEANS procedure of SAS (Statistical Analysis System, version 9.3). Analysis of variance was performed with GLM repeated measures, and the differences between groups were processed with Tukey's test and declared at the level $\mathrm{P}<0.05$ by using the model:

$$
\Upsilon_{i j}=\mu+D_{i}+S_{j}+(D \times S)_{i j}+e_{i j}
$$

in which $\Upsilon_{i j}=$ dependent observation, $\mu$ = overall mean, $D_{i}=$ effect of diet treatment, $S_{j}=$ effect of stage of lactation, $(D \times S)_{i j}=$ effect of interaction between diet and stage of lactation, and $e_{i j}=$ residual error. 
Table 1 - Ingredients of feed mixtures, chemical composition, and fatty acid concentration of feed mixtures and hay

\begin{tabular}{|c|c|c|c|c|}
\hline \multirow{2}{*}{ Component ( $\mathrm{g} \mathrm{kg}^{-1}$ as fed) } & \multicolumn{3}{|c|}{ Diet $^{1}$} & \multirow{2}{*}{ Hay } \\
\hline & Control (SBM) & $P$ & SFC & \\
\hline \multicolumn{5}{|l|}{ Ingredient composition } \\
\hline Corn & 705 & 581 & 678 & \\
\hline Barley & 100 & 100 & 50 & \\
\hline Soybean meal & 165 & 109 & 62 & \\
\hline Pea & - & 180 & - & \\
\hline Sunflower cake & - & - & 180 & \\
\hline Mineral premix ${ }^{2}$ & 30 & 30 & 30 & \\
\hline \multicolumn{5}{|c|}{ Chemical composition ( $\mathrm{g} \mathrm{kg}^{-1}$ dry matter) } \\
\hline Dry matter & 897.5 & 906.0 & 910.2 & 937.2 \\
\hline Crude protein & 140.7 & 145.5 & 152.9 & 99.3 \\
\hline Ether extract & 29.9 & 23.1 & 34.2 & 9.5 \\
\hline Crude fiber & 32.7 & 26.5 & 46.6 & 323.3 \\
\hline Ash & 39.3 & 45.1 & 47.6 & 55.9 \\
\hline NDF (\%) & 9.13 & 7.50 & 12.10 & 66.41 \\
\hline NFC (\%) & 69.88 & 71.13 & 64.43 & 17.12 \\
\hline $\operatorname{NEL}\left(\mathrm{MJ} \mathrm{kg}{ }^{-1}\right)$ & 7.71 & 7.70 & 7.69 & 3.41 \\
\hline \multicolumn{5}{|c|}{ Fatty acids (g $100 \mathrm{~g}^{-1}$ fatty acids) } \\
\hline C14:0 & 0.08 & 0.15 & 0.12 & 0.99 \\
\hline C16:0 & 16.15 & 17.03 & 16.20 & 38.70 \\
\hline C16:1 & 0.13 & 0.13 & 0.15 & 0.51 \\
\hline C17:0 & 0.10 & 0.13 & 0.10 & 0.57 \\
\hline C18:0 & 2.52 & 2.92 & 3.30 & 3.68 \\
\hline C18:1 c9 (OA) & 26.32 & 25.25 & 29.56 & 6.82 \\
\hline C18: 2 c9,12 (LA) & 51.19 & 49.57 & 46.85 & 18.06 \\
\hline $\mathrm{C} 20: 0$ & 0.43 & 0.49 & 0.46 & 1.15 \\
\hline C20:1 c11 & 0.31 & 0.34 & 0.30 & 0.54 \\
\hline C18:3 c9c12 c15 & 2.14 & 3.21 & 1.51 & 21.80 \\
\hline $\mathrm{C} 22: 0$ & 0.25 & 0.29 & 0.54 & 1.41 \\
\hline C20:4 & 0.07 & 0.09 & 0.09 & 0.84 \\
\hline $\mathrm{C} 24: 0$ & 0.31 & 0.36 & 0.39 & 1.36 \\
\hline SFA & 19.83 & 21.42 & 21.28 & 50.02 \\
\hline UFA & 80.17 & 78.58 & 78.72 & 49.98 \\
\hline MUFA & 26.76 & 25.72 & 30.26 & 8.64 \\
\hline PUFA & 53.40 & 52.86 & 48.46 & 41.34 \\
\hline
\end{tabular}

NDF - neutral detergent fiber; NFC - non-fiber carbohydrates; NEL - net energy for milk production; SFA - saturated fatty acids, UFA - unsaturated fatty acids; MUFA - monounsaturated fatty acids; PUFA - polyunsaturated fatty acids.

${ }^{1}$ SBM - soybean meal; SFC - soybean meal partially replaced with sunflower cake; P - soybean meal partially replaced with pea grain.

${ }^{2}$ Mineral premix: $18 \% \mathrm{Ca} ; 5 \%$ P; $9.5 \% \mathrm{Na} ; 2.00 \% \mathrm{Mg} ; 400,000 \mathrm{IU}$ vitamin A; 40,000 IU vitamin D; $500 \mathrm{mg}$ vitamin E; $4000 \mathrm{mg} \mathrm{Zn} ; 2000 \mathrm{mg} \mathrm{Mn}$; 60 mg I; 10 mg Co; 50 mg Se.

\section{Results}

By analyzing the gross composition of the milk of ewes, a significantly higher content of milk fat and lower concentration of urea were determined in group fed SFC compared with group fed SBM (Table 2). The content of remaining parameters in ewe milk did not differ significantly among groups with respect to protein source in the diets. Furthermore, stage of lactation had a significant effect on most of milk composition parameters, except fat content and SCC. Significant interaction of diet and stage of lactation was observed in urea milk concentration.

In comparison with milk produced by ewes fed SBM, milk of ewes fed SFC had significantly higher concentrations of C4:0, C17:1 c10, oleic, linoleic acid (LA), C18:0, C18:1 t9, C21:0, C22:0, C23:0, C24:0, and docosahexaenoic acid (DHA; C22:6) and lower concentrations of C8:0, C10:0, C12:0, C13:0, C14:0, C15:0, C16:1, C18:3 c6 c9 c12, and eicosahexaenoic acid (EPA, C20:5; Table 3). Milk of the group fed 
Table 2 - Milk composition of ewes fed feed mixtures containing soybean meal (SBM; control), sunflower cake (SFC), and pea grain (P)

\begin{tabular}{|c|c|c|c|c|c|c|c|}
\hline \multirow{2}{*}{ 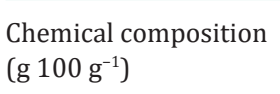 } & \multicolumn{3}{|c|}{ Diet } & \multirow{2}{*}{ SEM } & \multicolumn{3}{|c|}{ Effect } \\
\hline & SBM & $\mathrm{P}$ & SFC & & $\operatorname{Diet}(\mathrm{D})$ & Stage of lactation (S) & $\mathrm{D} \times \mathrm{S}$ \\
\hline Dry matter & 11.25 & 11.06 & 11.05 & 0.06 & 0.324 & 0.004 & 0.716 \\
\hline Fat & $4.31 b$ & $4.97 \mathrm{ab}$ & $5.17 \mathrm{a}$ & 0.13 & 0.003 & 0.124 & 0.057 \\
\hline Protein & 5.26 & 5.20 & 5.08 & 0.06 & 0.682 & $<0.001$ & 0.640 \\
\hline Lactose & 4.87 & 4.75 & 4.86 & 0.03 & 0.177 & 0.011 & 0.988 \\
\hline Urea $\left(\mathrm{mg} \mathrm{dL}^{-1}\right)$ & $40.50 \mathrm{a}$ & $39.20 \mathrm{a}$ & $28.72 b$ & 1.29 & $<0.001$ & $<0.001$ & $<0.001$ \\
\hline SCC (number $\mathrm{mL}^{-1}$ ) & 269,906 & 292,478 & 198,615 & 41,678 & 0.680 & 0.884 & 0.487 \\
\hline
\end{tabular}

SCC - somatic cell count; SEM - standard error of the mean.

a,b - Values with different letters in the rows differ significantly $(\mathrm{P}<0.05)$.

Table 3 - Concentration of milk fatty acids of ewes fed feed mixtures containing soybean meal (SBM; control), sunflower cake (SFC), and pea grain (P)

\begin{tabular}{|c|c|c|c|c|c|c|c|}
\hline \multirow{2}{*}{ Fatty acid (g $100 \mathrm{~g}^{-1}$ ) } & \multicolumn{3}{|c|}{ Diet } & \multirow{2}{*}{ SEM } & \multicolumn{3}{|c|}{ Effect } \\
\hline & SBM & $\mathrm{P}$ & $\mathrm{SFC}$ & & Diet (D) & Stage of lactation (S) & $\mathrm{D} \times \mathrm{S}$ \\
\hline $\mathrm{C} 4: 0$ & $1.06 \mathrm{~b}$ & $1.12 \mathrm{~b}$ & $1.22 \mathrm{a}$ & 0.02 & $<0.001$ & $<0.001$ & 0.178 \\
\hline C6:0 & 1.49 & 1.50 & 1.42 & 0.02 & 0.242 & 0.540 & 0.014 \\
\hline $\mathrm{C} 8: 0$ & $1.84 \mathrm{a}$ & $1.80 \mathrm{ab}$ & $1.62 \mathrm{~b}$ & 0.03 & 0.023 & 0.024 & 0.174 \\
\hline C10:0 & $6.95 a$ & $6.77 \mathrm{a}$ & $5.69 \mathrm{~b}$ & 0.15 & $<0.001$ & $<0.001$ & 0.065 \\
\hline C11:0 & 0.09 & 0.08 & 0.10 & 0.005 & 0.073 & $<0.001$ & $<0.001$ \\
\hline C12:0 & $4.89 \mathrm{a}$ & $4.75 a$ & $3.82 \mathrm{~b}$ & 0.12 & $<0.001$ & $<0.001$ & 0.012 \\
\hline $\mathrm{C} 13: 0$ & $0.14 \mathrm{a}$ & $0.13 a$ & $0.10 \mathrm{~b}$ & 0.004 & $<0.001$ & 0.017 & 0.847 \\
\hline C14:0 & $11.48 a$ & $12.00 \mathrm{a}$ & $10.28 b$ & 0.17 & $<0.001$ & $<0.001$ & 0.006 \\
\hline C14:1 & $0.14 \mathrm{ab}$ & $0.15 a$ & $0.12 \mathrm{~b}$ & 0.14 & 0.013 & $<0.001$ & 0.038 \\
\hline C15:0 & $1.55 \mathrm{a}$ & $1.45 a$ & $1.31 \mathrm{~b}$ & 0.03 & $<0.001$ & $<0.001$ & 0.569 \\
\hline C16:0 & $25.31 b$ & $26.80 a$ & $24.63 b$ & 0.23 & $<0.001$ & $<0.001$ & 0.009 \\
\hline C16:1 & $0.72 \mathrm{a}$ & $0.75 \mathrm{a}$ & $0.64 b$ & 0.01 & $<0.001$ & $<0.001$ & 0.411 \\
\hline $\mathrm{C} 17: 0$ & 1.20 & 1.21 & 1.13 & 0.02 & 0.143 & 0.102 & 0.156 \\
\hline C17:1 c10 & $0.29 \mathrm{~b}$ & $0.38 \mathrm{a}$ & $0.36 \mathrm{a}$ & 0.02 & 0.002 & $<0.001$ & $<0.001$ \\
\hline C18:0 & $12.75 b$ & $11.49 \mathrm{c}$ & $13.69 a$ & 0.19 & $<0.001$ & $<0.001$ & 0.007 \\
\hline C18:1 t9 & $1.62 \mathrm{~b}$ & $1.48 \mathrm{c}$ & $1.94 \mathrm{a}$ & 0.04 & $<0.001$ & $<0.001$ & 0.094 \\
\hline C18:1c9 & $23.39 b$ & $22.61 b$ & $25.87 a$ & 0.35 & $<0.001$ & $<0.001$ & 0.118 \\
\hline C18:2 t9 t12 & 0.16 & 0.16 & 0.19 & 0.007 & 0.065 & $<0.001$ & 0.050 \\
\hline C18:2 n-6 & $2.15 b$ & $2.30 \mathrm{~b}$ & $2.74 \mathrm{a}$ & 0.07 & 0.004 & 0.062 & 0.090 \\
\hline C20:0 & $0.53 a$ & $0.45 b$ & $0.50 \mathrm{a}$ & 0.01 & $<0.001$ & $<0.001$ & 0.077 \\
\hline C18:3 c6 c9 c12 & $0.05 a$ & $0.05 a$ & $0.02 b$ & 0.005 & 0.006 & 0.004 & $<0.001$ \\
\hline C20:1 & 0.12 & 0.10 & 0.09 & 0.01 & 0.161 & 0.016 & 0.784 \\
\hline C18:3 n-3 & 0.83 & 0.93 & 0.81 & 0.03 & 0.130 & $<0.001$ & 0.015 \\
\hline $\mathrm{C} 21: 0$ & $0.47 \mathrm{c}$ & $0.64 \mathrm{~b}$ & $0.84 \mathrm{a}$ & 0.03 & $<0.001$ & $<0.001$ & $<0.001$ \\
\hline C20:2 & 0.02 & 0.03 & 0.03 & 0.005 & 0.695 & 0.015 & 0.005 \\
\hline $\mathrm{C} 22: 0$ & $0.17 \mathrm{~b}$ & $0.14 \mathrm{c}$ & $0.21 \mathrm{a}$ & 0.01 & $<0.001$ & $<0.001$ & $<0.001$ \\
\hline C20:3 & 0.01 & 0.01 & 0.002 & 0.001 & 0.335 & 0.719 & 0.006 \\
\hline C20:4 & 0.14 & 0.12 & 0.13 & 0.01 & 0.460 & $<0.001$ & 0.002 \\
\hline $\mathrm{C} 23: 0$ & $0.13 \mathrm{~b}$ & $0.14 \mathrm{~b}$ & $0.18 \mathrm{a}$ & 0.01 & 0.002 & $<0.001$ & $<0.001$ \\
\hline $\mathrm{C} 22: 2$ & 0.06 & 0.07 & 0.06 & 0.01 & 0.462 & 0.061 & $<0.001$ \\
\hline $\mathrm{C} 24: 0$ & $0.06 \mathrm{~b}$ & $0.08 \mathrm{ab}$ & $0.11 \mathrm{a}$ & 0.01 & $<0.001$ & $<0.001$ & $<0.001$ \\
\hline $\mathrm{C} 20: 5$ (EPA) & $0.07 \mathrm{~b}$ & $0.12 \mathrm{a}$ & $0.05 b$ & 0.01 & $<0.001$ & 0.017 & 0.436 \\
\hline $\mathrm{C} 24: 1$ & $0.05 a b$ & $0.06 a$ & $0.03 b$ & 0.005 & 0.023 & $<0.001$ & $<0.001$ \\
\hline C22:6 (DHA) & $0.02 \mathrm{~b}$ & $0.07 a$ & $0.05 \mathrm{ab}$ & 0.005 & 0.003 & 0.967 & 0.100 \\
\hline
\end{tabular}

SEM - standard error of the mean.

$a, b$ - Values with different letters in the rows differ significantly $(\mathrm{P}<0.05)$. 
P had higher concentration of DHA, EPA, C16:0, C17:1 C10, C21:0 and lower concentration of C18:0, C18:1 t9, C20:0, and C22:0. When compared with other groups, concentrations of lauric, myristic, and palmitic acids were lower in ewe milk fed SFC. When compared with the group fed SBM, milk of ewes fed SFC had significantly higher concentration of LA.

Fatty acid composition in milk statistically varied when compared with milk from the group fed SBM (Tables 3 and 4). Interaction of diet and stage of lactation had significant effect on the concentration of C11:0, C14:0, C16:0, C18:0, as well as on $\alpha$-linolenic acid (C18:3 n-3) and most of the fatty acids with 20 carbon atoms. In this research, stage of lactation had significant influence on the concentration of most of the fatty acids in ewe milk.

By analyzing the groups of fatty acids in milk, as well as AI, TI, and $\Delta^{9}$-desaturase index, it was proven that milk of sheep fed SFC had significantly higher concentration of unsaturated fatty acids (UFA), monounsaturated fatty acids (MUFA), n-6, and n-6:n-3, and lower saturated fatty acids (SFA), $\mathrm{n}-3$, AI, and TI than milk of both groups fed P and SBM. In addition, significantly lower index for C16:1/C16:0 was determined in group fed SFC when compared with the group fed SBM. Significant influence of diet and stage of lactation interaction for concentrations of n-3, AI, TI, and HI was also observed. The lowest n-6:n-3 ratio was determined in the group fed P, followed by groups fed SBM and SFC. The group fed SFC had significantly higher ratio than other groups. Interaction of diet and stage of lactation had significant effect on most fatty acid groups (SFA, UFA, MUFA), as well as on $\mathrm{n}-3 \mathrm{AI}, \mathrm{TI}$, and $\mathrm{HI}$.

By analyzing the biochemical parameters, partial replacement of SBM with SFC reduced the concentration of total protein, globulin, AST, and GGT enzymes and increased BHB blood concentration, while no significant differences in biochemical blood parameters were found when replacing SBM with $\mathrm{P}$ (Table 5). Significant interaction was determined between diet and stage of lactation referring to the concentration of glucose, urea, albumin, cholesterol, NEFA, BHB, globulin, as well as activity of ALT and ALP. Significant changes in the concentrations of glucose, urea, total proteins, triglycerides, BHB, and AST and GGT enzyme activities were determined.

Table 4 - Groups of milk fatty acids of ewes fed feed mixtures containing soybean meal (SBM; control), sunflower cake (SFC), and pea grain (P)

\begin{tabular}{|c|c|c|c|c|c|c|c|}
\hline \multirow{2}{*}{ Fatty acid (g $\left.100 \mathrm{~g}^{-1}\right)$} & \multicolumn{3}{|c|}{ Diet } & \multirow{2}{*}{ SEM } & \multicolumn{3}{|c|}{ Effect } \\
\hline & SBM & $\mathrm{P}$ & SFC & & Diet (D) & Stage of lactation (S) & $\mathrm{D} \times \mathrm{S}$ \\
\hline SFA & $70.12 \mathrm{a}$ & $70.59 a$ & $66.86 \mathrm{~b}$ & 0.42 & $<0.001$ & $<0.001$ & 0.047 \\
\hline UFA & $29.88 b$ & $29.41 b$ & $33.14 a$ & 0.42 & $<0.001$ & $<0.001$ & 0.047 \\
\hline MUFA & $26.34 b$ & $25.54 b$ & $29.05 a$ & 0.38 & $<0.001$ & $<0.001$ & 0.085 \\
\hline PUFA & 3.54 & 3.88 & 4.09 & 0.09 & 0.062 & 0.012 & 0.105 \\
\hline$n-6$ & $2.52 \mathrm{~b}$ & $2.67 \mathrm{~b}$ & $3.11 \mathrm{a}$ & 0.07 & 0.004 & 0.184 & 0.228 \\
\hline$n-3$ & $1.00 \mathrm{~b}$ & $1.14 \mathrm{a}$ & $0.92 \mathrm{~b}$ & 0.03 & 0.003 & $<0.001$ & 0.022 \\
\hline$n-6: n-3$ & $2.70 \mathrm{~b}$ & $2.43 \mathrm{~b}$ & $3.88 \mathrm{a}$ & 0.12 & $<0.001$ & 0.251 & 0.589 \\
\hline AI & $2.61 \mathrm{a}$ & $2.76 a$ & $2.16 \mathrm{~b}$ & 0.06 & $<0.001$ & $<0.001$ & 0.006 \\
\hline TI & $1.71 \mathrm{a}$ & $1.75 \mathrm{a}$ & $1.56 \mathrm{~b}$ & 0.03 & 0.002 & $<0.001$ & 0.035 \\
\hline $\mathrm{HI}$ & $0.40 \mathrm{~b}$ & $0.38 b$ & $0.49 a$ & 0.011 & $<0.001$ & $<0.001$ & 0.014 \\
\hline \multicolumn{8}{|l|}{$\Delta^{9}$-desaturase index } \\
\hline $\mathrm{C} 14: 1 / \mathrm{C} 14: 0$ & 0.012 & 0.013 & 0.012 & 0.0004 & 0.537 & $<0.001$ & 0.393 \\
\hline $\mathrm{C} 16: 1 / \mathrm{C} 16: 0$ & $0.029 a$ & $0.028 \mathrm{ab}$ & $0.026 b$ & 0.0004 & 0.037 & 0.157 & 0.394 \\
\hline C18:1/C18:0 & 1.85 & 1.98 & 1.90 & 0.02 & 0.058 & 0.677 & 0.264 \\
\hline
\end{tabular}

SFA - saturated fatty acids; UFA - unsaturated fatty acids; MUFA - monounsaturated fatty acids; PUFA - polyunsaturated fatty acids; AI atherogenic index; TI - thrombogenic index; HI - health index; SEM - standard error of the mean.

$\mathrm{a}, \mathrm{b}$ - Values with different letters in the rows differ significantly $(\mathrm{P}<0.05)$. 
Table 5 - Blood biochemical parameters of ewes fed feed mixtures containing soybean meal (SBM; control), sunflower cake (SFC), and pea grain (P)

\begin{tabular}{|c|c|c|c|c|c|c|c|}
\hline \multirow{2}{*}{ Parameter $\left(\mathrm{mmol} \mathrm{L}^{-1}\right)$} & \multicolumn{3}{|c|}{ Diet } & \multirow{2}{*}{ SEM } & \multicolumn{3}{|c|}{ Effect } \\
\hline & SBM & $\mathrm{P}$ & SFC & & Diet (D) & Stage of lactation (S) & $\mathrm{D} \times \mathrm{S}$ \\
\hline Glucose & 3.98 & 3.81 & 3.81 & 0.06 & 0.458 & 0.027 & 0.019 \\
\hline Urea & $4.38 \mathrm{ab}$ & $3.79 b$ & $4.49 \mathrm{a}$ & 0.12 & 0.033 & 0.017 & 0.006 \\
\hline Protein $\left(\mathrm{g} \mathrm{L}^{-1}\right)$ & $61.67 \mathrm{a}$ & $60.95 a$ & $56.40 \mathrm{~b}$ & 0.70 & 0.005 & 0.127 & 0.115 \\
\hline Albumin $\left(\mathrm{g} \mathrm{L}^{-1}\right)$ & 25.71 & 25.27 & 24.60 & 0.32 & 0.320 & 0.003 & 0.349 \\
\hline Globulin $\left(\mathrm{g} \mathrm{L}^{-1}\right)$ & $35.96 a$ & $34.60 \mathrm{ab}$ & $31.81 b$ & 0.71 & 0.045 & 0.002 & 0.331 \\
\hline Cholesterol & 1.29 & 1.26 & 1.35 & 0.02 & 0.611 & 0.007 & 0.535 \\
\hline Triglycerides & $0.21 b$ & $0.19 \mathrm{~b}$ & $0.24 \mathrm{a}$ & 0.006 & 0.004 & 0.063 & 0.682 \\
\hline HDL cholesterol & 0.89 & 0.82 & 0.87 & 0.02 & 0.237 & 0.051 & 0.787 \\
\hline LDL cholesterol & 0.32 & 0.37 & 0.34 & 0.01 & 0.335 & 0.320 & 0.118 \\
\hline NEFA & 0.18 & 0.19 & 0.23 & 0.02 & 0.415 & $<0.001$ & 0.403 \\
\hline BHB & $0.34 \mathrm{~b}$ & $0.39 \mathrm{ab}$ & $0.43 a$ & 0.01 & 0.001 & 0.036 & 0.234 \\
\hline $\operatorname{AST}\left(\mathrm{U} \mathrm{L}^{-1}\right)$ & $118.89 a$ & $114.34 \mathrm{ab}$ & $104.14 b$ & 2.43 & 0.028 & 0.119 & 0.014 \\
\hline $\operatorname{ALT}\left(\mathrm{U} \mathrm{L}^{-1}\right)$ & 22.40 & 23.04 & 22.74 & 0.52 & 0.654 & 0.028 & 0.387 \\
\hline $\operatorname{ALP}\left(U^{-1}\right)$ & 113.53 & 121.32 & 117.42 & 4.45 & 0.783 & 0.010 & 0.877 \\
\hline GGT $\left(\mathrm{U} \mathrm{L}^{-1}\right)$ & $60.29 a$ & $59.38 \mathrm{a}$ & $49.56 b$ & 1.41 & 0.004 & 0.056 & 0.502 \\
\hline $\mathrm{CK}\left(\mathrm{U} \mathrm{L}^{-1}\right)$ & 113.38 & 118.06 & 91.93 & 6.14 & 0.153 & 0.096 & 0.125 \\
\hline
\end{tabular}

NEFA - non-esterified fatty acids; BHB - $\beta$-hydroxibutyrate; AST - aspartate aminotransferase; ALT - alanine aminotransferase; ALP - alkaline phosphatase; GGT - $\gamma$-glutamyl transferase; CK - creatine kinase; SEM - standard error of the mean.

$\mathrm{a}, \mathrm{b}$ - Values in rows with different letters differ significantly $(\mathrm{P}<0.05)$

\section{Discussion}

Ewes fed SFC had higher milk fat content than ewes fed SBM. This is probably related to the higher content of fat in experimental feed due to inclusion of SFC (Table 1). This is in accordance with previous report for dairy sheep fed diets supplemented with lipids (Caja and Bocquier, 2000; Toral et al., 2011). The quality of ewe milk mainly depends on fat and protein concentrations, which are valuable parameters in production of cheese (Pellegrini et al., 1997) and one of the main objectives of dairy sheep farming. The tendency of lower milk protein concentration found in group fed SFC was in agreement with the increased milk fat concentration. It is well known that milk fat is the major energy cost of milk synthesis (Schmidt, 1971). Sarhan (2011) determined lower concentration of urea in milk when replacing soybean meal with peas in ewe diets. Similar decrease of urea concentration in milk was determined in group of ewes fed SFC in the current study. Urea concentration in milk is an indicator of balanced energy and proteins in the diet, meaning that higher urea concentrations in milk indicate excessive protein concentrations in feed (Bendelja et al., 2009). Liponi et al. (2007) determined a significant decrease of protein content in ewe milk when completely replacing soybean meal. Bonanno et al. (2015) reported similar changes in the chemical composition of milk and in the number of somatic cells as it is the case in the present study. According to Renna et al. (2012), peas can be effectively used as a source of protein instead of soybean in low- or high-productive dairy sheep. Kraličkova et al. (2012) and Novotna et al. (2009) determined significant changes in the chemical composition of organic ewe milk during various stages of lactation.

Milk fatty acids composition statistically varied when compared with milk from the group fed SBM, which is related to the protein and fat source in the diets (Tables 3 and 4). In comparison with milk produced by ewes fed SBM, milk of ewes fed SFC had lower concentrations of C8:0, C10:0, and most of the medium-chain fatty acids, as well as higher concentration of oleic, LA, C18:0, and some individual long-chain fatty acids. The mentioned changes could be related to changes in the diets (Table 1), as well as to different formation of individual fatty acids within the rumen or in the mammary gland.

The relation of changes in C12:0, C14:0, and C16:0 could be influenced by their concentrations in the diets. Similar changes were observed by Renna et al. (2012). These fatty acids were found to 
be detrimental from the point of view of cardiovascular disease control (Jensen, 2002). Fatty acids in milk from C6:0 to C10:0 are important in human health, being used in the treatment of metabolic illness (Sanz Sampelayo et al., 2007). Saturated fatty acids from C12:0 to C16:0 are known for their hypercholesterolaemic effect, by increasing LDL cholesterol (Ohlsson, 2010). Milk fatty acids from C14:0 to C17:0 are mainly derived from the biosynthesis of bacteria living in the rumen, thus reflecting the changes in the rumen bacteria populations and being markers of the correspondent fermentation activity (Vlaeminck et al., 2006).

The dominant fatty acid in ewe diets was LA (C18:2 n-6), with concentration higher than $50 \%$, followed by oleic acid. This corresponds to the results published by Bonanno et al. (2015), Lanza et al. (2011), and Renna et al. (2012). When compared with SBM, milk of ewes fed SFC had significantly higher concentration of LA. Similar results were obtained by Hervás et al. (2008), when feeding sheep feed mixtures supplemented with sunflower oil, considering concentration of C4:0-C18:2 (n-6). Križova et al. (2016) also obtained higher concentration of LA in milk of cows fed diet with inclusion of sunflower pomace.

Interaction of diet and stage of lactation had significant effect on the concentration of C11:0, C14:0, C16:0, C18:0, as well as on $\alpha$-linolenic acid (C18:3 n-3) and most of the fatty acids with 20 carbon atoms. This indicated interdependence of feed and lactation stage. In this research, stage of lactation had significant influence on the concentration of most fatty acids in ewe milk. Sinanoglou et al. (2015) also observed similar changes in concentrations of C12:0, C14:0, C16:0, as well as relations with source of proteins in the diet and changes in concentration of C14:0, C16:0, C18:0, C18:1 c9, and C24:0. Similar results for concentration of fatty acids in ewe milk during lactation were reported by Molina et al. (2005). De la Fuente et al. (2009) conducted the research in Spain on milk of Churra sheep to determine significant effect of lactation on the concentration of most fatty acids. These authors concluded that the main changes in concentrations of fatty acids occurred in early lactation, while a relatively stable concentration of fatty acids pattern was obtained in mid and late lactation.

Long-chain fatty acids in milk of the pea group showed lower stearic, oleic, and LA concentration in comparison with ewes fed mixed concentrated feed containing maize and soybean (Bonanno et al., 2015). Renna et al. (2012) determined higher amount of SFA in pea concentrate than in commercial concentrate containing sunflower meal and soybean seeds. In the present study, milk from ewes fed diet with SFC had higher concentrations of LA and oleic acid than other groups (SBM and P), which seemed to reflect the dietary levels and intakes of these long-chain UFA. The research by Jenkins and Adams (2002) determined that high intake of LA inhibited the complete fatty acid biohydrogenation in the rumen environment. The reduced biohydrogenation results in the increased content of LA and other fatty acids produced as a result of incomplete biohydrogenation. Bonanno et al. (2015) determined that LA was the predominant fatty acid in all diets, followed by oleic acid in mixed concentrated feed containing maize and soybean, which provided higher amounts of LA and oleic acid than the pea meal, due to their higher lipid content. This is the reason for the lower milk content of short- and medium-chain fatty acids, since the UFA are recognized as inhibitors of the activity of lipogenic enzymes responsible for the de novo fatty acid synthesis in the mammary gland (Chilliard and Ferlay, 2004). Lanza et al. (2011) determined positive effect of pea diet in lamb meat as it increased the level of n-3 fatty acids. Glasser et al. (2008) determined that fatty acids with 20 carbons or more were generally weakly affected by lipid supplement applied in the form of oil seeds or protected oil seeds.

The concentration of MUFA in ewe milk corresponded to their content in diets (Table 1). Type of diet did not significantly affect the content of PUFA. The highest total n-3 fatty acids in ewe milk in the group fed P led to the lowest n-6:n-3 ratio, which, according to Simopoulos (2002), should be an ideal $1: 1$. When compared with the other groups, the group fed SFC had significantly higher ratio, which is related to their content in feed. In all diets, the n-6:n-3 ratio was lower and more favorable than level $(<5)$ recommended by FAO/WHO (1994). The highest total $n-3$ fatty acids in ewe milk in group fed P led to the lowest n-6:n-3 ratio. A similar conclusion was reported by Bonanno et al. (2015).

R. Bras. Zootec., 48:e20180140, 2019 
Lower AI in the group fed SFC than in other groups suggests a more favorable composition of milk from this group. The calculated AI, which is used as a risk indicator of cardiovascular diseases (Ulbricht and Southgate, 1991), was determined based on concentration of lauric, myristic, palmitic, and UFA in milk. Higher intake of these fatty acids increases blood LDL cholesterol, whereas a greater intake of UFA has the reverse effect (Fernandez and West, 2005); the present research confirmed a similar effect (Table 5). The research of Bonanno et al. (2015) determined the improvement of health-promoting index in milk of ewes fed mixed concentrated feed containing maize and soybean, which was assigned as a health value of milk fat. Group fed SBM had $\Delta^{9}$-desaturase index of C16:0 higher than the group fed SFC, but $\Delta^{9}$-desaturase index of C14:0 and C18:0 did not differ among groups. Bonanno et al. (2015) determined $\Delta^{9}$-desaturase index of C16:0, which was higher in milk from ewes fed mixed concentrated feed containing maize and soybean than in milk from ewes fed pea. Moreover, the health index in the present study was higher in group fed SFC than in the group fed SBM and P as a result of higher concentration of UFA in SFC.

Partial replacement of SBM with SFC reduced the concentration of total protein, globulin, AST, and GGT enzymes and increased BHB blood concentration, while no significant differences in biochemical blood parameters were found when replacing SBM with P. Interaction between diet and stage of lactation influenced the concentration of glucose, urea, albumin, cholesterol, NEFA, BHB, globulin, as well as activity of ALT and ALP. Tufarelli et al. (2012) reported that cows fed diets in which SBM was replaced by pea grains had reduced blood and milk urea concentrations, which almost certainly occurred because of decreased degradability of pea protein leading to the decreased ammonia level in the rumen and urea level in milk and blood. In general, changes in urea concentration are correlated with the content of ruminal ammonia, which depends on the metabolic activity of ruminal microorganisms that transform ammonia nitrogen into a bacterial protein, a process that requires energy (Gonzaga Neto et al., 2015). The above-mentioned could be related to higher content of crude protein in diet of ewes with the addition of SFC (Table 1). Tufarelli et al. (2012) also determined the increase of BHB concentration in blood of cows fed diet with addition of peas compared with SBM, although without significant differences. When feeding lactating cows diets in which soybean meal was replaced with peas, Petit et al. (1997) did not find significant differences in the urea concentration, total protein, and NEFA in the blood. Similar non-significant trend was reported by Liponi et al. (2007) for most of the biochemical parameters and the activity of enzymes in blood of lactating ewes fed diets in which soybean meal was replaced by pea. Similar results were also published by Masoero et al. (2006), as they found non-significantly lower concentration of cholesterol, total protein, glucose, urea, globulin, and AST activity and higher NEFA in the group of cows fed a mixture containing peas compared with those fed diet with soybean meal. In the present study, significant changes in the blood concentrations of glucose, urea, total proteins, triglycerides, BHB, and AST and GGT enzyme activities were determined as a consequence of stage of lactation, which agrees with the results observed by Antunović et al. (2011).

\section{Conclusions}

Partial replacement of soybean meal with pea grains does not influence the composition of milk but increases total n-3 fatty acids. Feeding ewes sunflower cake increases fat and decreases urea concentration in milk, which may be beneficial for cheese production; it increases oleic and linoleic acid, with slightly increased n-6:n-3 ratio in ewe milk. Determined blood parameters suggests an adequate level of protein and energy available to the ewes fed pea or sunflower cake. These protein sources are an appropriate partial substitution for soybean meal and dietary components used in diets for dairy ewes in organic farming.

\section{Acknowledgments}

The research required for the present study was part of the VIP project (2015-13/13) financed by the Ministry of Agriculture, Republic of Croatia. 


\section{References}

Alves, F. J. L.; Ferreira, M. A.; Urbano, S. A.; Andrade, R. P. X.; Silva, A. E. M.; Siqueira, M. C. B.; Oliveira, J. P. F. and Silva, J. L. 2016. Performance of lambs fed alternative protein sources to soybean meal. Revista Brasileira de Zootecnia 45:145-150. https://doi.org/10.1590/S1806-92902016000400001

Antunović, Z.; Novoselec, J.; Šperanda, M.; Vegara, M.; Pavić, V.; Mioč, B. and Đidara, M. 2011. Changes in biochemical and hematological parameters and metabolic hormones in Tsigai ewes blood in the first third of lactation. Archives Animal Breeding 54:535-545. https://doi.org/10.5194/aab-54-535-2011

Antunović, Z.; Novoselec, J.; Klir, Ž. and Đidara, M. 2013. Inclusion of peas as protein sources in the diet of dairy goats in organic breeding. Macedonian Journal of Animal Science 3:63-67.

Antunović, Z.; Novoselec, J. and Klir, Ž. 2017. Hematological parameters in ewes during lactation in organic farming. Agriculture 23:46-52.

Bendelja, D.; Antunac, N.; Mikulec, N.; Vnučec, I.; Mašek, T.; Mikulec, Ž. and Havranek, J. 2009. Urea concentration in sheep'milk. Mljekarstvo 59:3-10.

Bonanno, A.; Di Grigoli, A.; Vitale, F.; Alabiso, M.; Giosuè, C.; Mazza, F. and Todaro, M. 2015. Legume grain-based supplement in dairy sheep diet: effects on milk yield, composition and fatty acid profile. Animal Production Science 56:130-140. https://doi.org/10.1071/AN14019

Caja, G. and Bocquier, F. 2000. Effects of nutrition on the composition of sheep's milk. Cahier Options Mediterranees 52:59-74.

Chen, S.; Bobe, G.; Zimmerman, S.; Hammond, E. G.; Luhman, C. M.; Boystoln, T. D.; Freeman, A. E. and Beitz, D. C. 2004. Physical and sensory properties of dairy products from cows with various milk fatty acid compositions. Journal of Agricultural and Food Chemistry 52:3422-3428. https://doi.org/10.1021/jf035193z

Chilliard, Y. and Ferlay, A. 2004. Dietary lipids and forages interactions on cow and goat milk fatty acid composition and sensory properties. Reproduction Nutrition Development 44:467-492. https://doi.org/10.1051/rnd:2004052

Cozzi, G.; Boukha, A.; Contiero, B. and Gottardo, F. 2010. Extruded pea (Pisum sativum) as alternative to soybean protein for dairy cows feeding in organic Alpine farms. Italian Journal of Animal Science 9:194-199.

De la Fuente, L. F.; Barbosa, E.; Carriedo, J. A.; Gonzalo, C.; Arenas, R.; Fresno, J. M. and San Primitivo, F. 2009. Factors influencing variation of fatty acids content in ovine milk. Journal of Dairy Science 92:3791-3799. https://doi.org/10.3168/jds.2009-2151

European Union. 2007. Council Regulation (EC) No. 834/2007 on organic production and labeling of organic products with regard to organic production, labeling and control. Official Journal of the European Union. Available at: <https://eurlex.europa.eu/legal-content/EN/TXT/PDF/?uri=CELEX:32007R0834\&from=EN>. Accessed on: June 4, 2018.

FAO/WHO. 1994. Fats and oils in human nutrition. Report of a joint FAO/WHO expert consultation. FAO Food and Nutrition Paper 57. Food and Agriculture Organization, Rome.

Fernandez, M. L. and West, K. L. 2005. Mechanisms by which dietary fatty acids modulate plasma lipids. Journal of Nutrition 135:2075-2078. https://doi.org/10.1093/jn/135.9.2075

Foss. 2001. Determination of acid detergent fibre (ADF) and acid detergent lignin in feed and forage using FiberCap ${ }^{\mathrm{TM}}$ 2021/2023 in agreement with EN ISO 13906:2008. Foss Tecator AB, Sweeden.

Glasser, F.; Ferlay, A. and Chilliard, Y. 2008. Oilseed lipid supplements and fatty acid composition of cow milk: a metaanalysis. Journal of Dairy Science 91:4687-4703. https://doi.org/10.3168/jds.2008-0987

Goes, R. H. T. B.; Sousa, K. A.; Guerrero, A.; Cerilo, S. L. N.; Fernandes, A. R. M.; Penha, D. S. and Prado, I. N. 2017. Replacement of soybean meal by sunflower cake in heifers finished on pasture: meat quality. Animal Production Science 58:2126-2131. https://doi.org/10.1071/AN16791

Gonzaga Neto, S.; Oliveira, R. L.; Lima, F. H. S.; Medeiros, A. N.; Bezerra, L. R.; Viégas, J.; Nascimento Jr., N. G. and Freitas Neto, M. D. 2015. Milk production, intake, digestion, blood parameters, and ingestive behavior of cows supplemented with by-products from the biodisel industry. Tropical Animal Health and Production 47:191-200. https://doi.org/10.1007/ s11250-014-0706-2

Herdt, T. H.; Rumbeiha, W. and Braselton, W. E. 2000. The use of blood analyses to evaluate mineral status in livestock. Veterinary Clinics of North America: Food Animal Practice 16:423-444. https://doi.org/10.1016/S0749-0720(15)30078-5

Hervás, G.; Luna, P.; Mantecón, A. R.; Castañares, N.; De la Fuente, M. A.; Juarez, M. and Frutos, P. 2008. Effect of diet supplementation with sunflower oil on milk production, fatty acid profile and ruminal fermentation in lactating dairy ewes. Journal of Dairy Research 75:399-405. https://doi.org/10.1017/S0022029908003506

Jenkins, T. C. and Adams, C. S. 2002. The biohydrogenation of linoleamide in vitro and its effects on linoleic acid concentration in duodenal contents of sheep. Journal of Animal Science 80:533-540. https://doi $\operatorname{org} / 10.2527 / 2002.802533 x$

Jensen, R. G. 2002. The composition of bovine milk lipids: January 1995 to December 2000. Journal of Dairy Science 85:295-350. https://doi.org/10.3168/jds.S0022-0302(02)74079-4

R. Bras. Zootec., 48:e20180140, 2019 
Jezierny, D.; Moinsenthin, R. and Bauer, E. 2010. The use of grain legumes as a protein source in pig nutrition: a review. Animal Feed Science and Technology 157:111-128.

Kraličkova, Š.; Pokorna, M. and Filipčik, R. 2012. Effect of parity and stage of lactation on milk yield, composition and quality of organic sheep milk. Acta Universitatis Agriculturae et Silviculturae Mendelianae Brunensis 1:71-78.

Križova, L.; Hanus, O.; Špička, J.; Samkova, E.; Frelich, J.; Richter, M.; Vesely, A. and Roubal, P. 2016. Alternative supplemental mixture for organic dairy herds to maintain desirable milk fatty acid profile throughout the indoor feeding period. Animal Science Papers and Reports 34:25-40.

Lanza, M.; Fabro, C.; Scerra, M.; Bella, M.; Pagano, R.; Brogna, D. M. R. and Pennisi, P. 2011. Lamb meat quality and intramuscular fatty acids composition as affected by concentrates including different legume seeds. Italian Journal of Animal Science 10:87-94. https://doi.org/10.4081/ijas.2011.e18

Liponi, G. B.; Casini, M.; Martini, M. and Gatta, D. 2007. Faba bean (Vicia faba minor) and pea seeds (Pisum sativum), a protein sources in lactating ewes' diets. Italian Journal of Animal Science 6:309-311. https://doi.org/10.4081/ijas.2007.1s.309

Masoero, F.; Moschini, M.; Fusconi, G. and Piva, G. 2006. Raw, extruded and expanded pea (Pisum sativum) in dairy cows diets. Italian Journal of Animal Science 5:237-247. https://doi.org/10.4081/ijas.2006.237

Molina, P.; Althaus, R.; Nagel, O.; Muelas, R. and Fernandez, N. 2005. Composition of free fatty acids and lipase activity in ewes' milk throughout the lactation period. Revista FAVE-Ciencias Veterinarias 4:71-75. https://doi.org/10.14409/ favecv.v4i1/2.1417

Nagalakshmi, D.; Dhanalakshmi, K. and Himabindu, D. 2011. Replacement of groundnut cake with sunflower and karanj seed cakes on performance, nutrient utilization, immune response and carcass characteristics in Nellore lams. Small Ruminant Research 97:12-20. https://doi.org/10.1016/j.smallrumres.2011.02.003

Novotna, L.; Kuchtik, J.; Šustova, K.; Zapletal, D. and Filipčik, R. 2009. Effects of lactation stage and parity on milk yield, composition and properties of organic sheep milk. Journal of Applied Animal Research 36:71-76. https://doi.org/10.10 80/09712119.2009.9707034

Offor, I. F; Ehiri, R. C. and Njoku, C. N. 2014. Proximate nutritional analysis and heavy metal composition of dried Moringa Oleifera leaves from Oshiri Onicha L.G.A, Ebonyi State, Nigeria. Journal of Environmental Science, Toxicology and Food Technology 8:57-62. https://doi.org/10.9790/2402-08115762

Ohlsson, L. 2010. Dairy products and plasma cholesterol levels. Food \& Nutrition Research 54:5124. https://doi. org/10.3402/fnr.v54i0.5124

Onwuka, G. I. 2005. Food Analysis and Instrumentation: Theory and practice. Naphthali Prints, Lagos, Nigeria.

Pearson, D. A. 1976. The chemical analysis of foods. 7th ed. Churchill Livingstone, Scotland. p.6-25.

Pellegrini, 0.; Remeuf, F.; Rivemale, M. and Barillet, F. 1997. Renneting properties of milk from individual ewes: Influence of genetic and non-genetic variables, and the relationship with physicochemical characteristics. Journal of Dairy Research 64:355-366. https://doi.org/10.1017/S0022029997002203

Petit, H. V.; Rioux, R. and Ouellet, D. R. 1997. Milk production and intake of lactating cows fed raw or extruded peas. Journal of Dairy Science 80:3377-3385. https://doi.org/10.3168/jds.S0022-0302(97)76313-6

Renna, M.; Cornale, P.; Lussiana, C.; Malafatto, V.; Forina, R.; Mimosi, A. and Battaglini, L. M. 2012. Use of Pisum sativum (L.) as alternative protein resource in diets for dairy sheep: Effect on milk yield, gross composition and fatty acid profile. Small Ruminant Research 102:142-150. https://doi.org/10.1016/j.smallrumres.2011.07.007

Russel, A. 1991. Body condition scoring of sheep. p.3. In: Sheep and goat practice. Boden, E., ed. Bailliere Tindall, Philadelphia.

Santos, E. M.; Ferreira, L. D. S.; Terra, E. D. L.; Bumbieris, V. H. J.; Azambuja, E. L. R.; Mizubuti, I. Y. and Souza, A. P. F. 2015 Sunflower cake in diets for lambs: intake, digestibility, nitrogen balance and rumen parameters. Semina: Ciências Agrárias 36:2247-2258.

Sanz Sampelayo, M. R.; Chilliard, Y.; Schmidely, P. and Boza, J. 2007. Influence of type of diet on the fat constituents of goat and sheep milk. Small Ruminant Research 68:42-63. https://doi.org/10.1016/j.smallrumres.2006.09.017

Sarhan, M. 2011. Use of legume grains in organic animal feeding. Effect on sheep milk yield and quality. Università degli Studi di Palermo, Facoltà di Agraria di Palermo, Dipartimento DEMETRA.

Schmidt, G. H. 1971. Biology of lactation. W. H. Freeman and Company, San Francisco.

Simopoulos, A. P. 2002. The importance of the ratio of omega-6/omega-3 essential fatty acids. Biomedicine \& Pharmacotherapy 56:365-379.

Sinanoglou, V. J.; Koutsouli, P.; Fotakis, C.; Sotiropoulou, G.; Cavouras, D. and Bizelis, I. 2015. Assessment of lactating stage and breed effect on sheep milk fatty acid profile and lipid quality indices. Dairy Science and Technology 95:509-531. https://doi.org/10.1007/s13594-015-0234-5

Toral, P. G.; Gómez-Cortés, P.; Frutos, P.; de la Fuente, M. A.; Juárez, M. and Hervás, G. 2011. Milk production and fatty acid profile after three weeks of diet supplementation with sunflower oil and marine algae in dairy ewes. p.337-342. 
In: Challenging strategies to promote the sheep and goat sector in the current global context. Ranilla, M. J.; Carro, M. D.; Ben Salem, H.; Morand-Fehr, P., eds. CIHEAM/CSIC/Universidad de León/FAO, Zaragoza. Options Méditerranéennes: Série A. Séminaires Méditerranéen: Serie A.

Tufarelli, V.; Naz, S.; Khan, R. U.; Mazzei, D. and Laudadio, V. 2012. Milk quality, manufacturing properties and blood biochemical profile from dairy cows fed peas (Pisum sativum L.) as dietary protein supplement. Archives Animal Breeding 55:132-139. https://doi.org/10.5194/aab-55-132-2012

Trajković, J.; Mirić, M.; Baras, J. and Šiler, S. 1983. Analize životnih namirnica. p.786. Faculty of Technology and Metallurgy, Belgrade, Serbia.

Ulbricht, T. L. V. and Southgate, D. A. T. 1991. Coronary heart-disease 7 dietary factors. Lancet 338:985-992. https://doi. org/10.1016/0140-6736(91)91846-M

Vlaeminck, B.; Fievez, V.; Cabrita, A. R. J.; Fonseca, A. J. M. and Dewhurst, R. J. 2006. Factors affecting odd- and branched-chain fatty acids in milk: a review. Animal Feed Science and Technology 131:389-417. https://doi.org/10.1016/j.anifeedsci.2006.06.017

Wanderley Junior, M. A.; Santos, C. L.; Lôbo, I. P.; Junqueira, R. S.; Lima, L. P.; Farias, T. J.; Santos, J. L.; Silva, A. M. 2018. Fatty acid composition in muscles from lambs fed diets containing agroindustrial co-products. Revista Brasileira de Zootecnia 47:e20170333. https://doi.org/10.1590/rbz4720170333

Whitney, T. R.; Waldron, D. F. and Willingham, T. D. 2009. Evaluating nutritional status of Dorper and Rambouillet ewes in range sheep production. Sheep \& Goat Research Journal 24:10-16. 